\title{
IUCN Red List of Ecosystems: Implications for public policy
}

Running tittle: Implications of IUCN RLE for public policy

Alberto J. Alaniz ${ }^{* 1,2,3}$, Jorge F. Perez-Quezada ${ }^{1,4}$, Mauricio Galleguillos ${ }^{1,5}$, Alexis E.

Vásquez $^{6}$, David A. Keith ${ }^{7,8,9,10}$

${ }^{1}$ Department of Environmental Science and Natural Renewable Resources, Universidad de Chile, Santiago, Chile.

${ }^{2}$ Laboratory of Biological Conservation, Technological Faculty, Universidad de Chile, Santiago, Chile.

${ }^{3}$ Center for Spatial Ecology and Environment- Ecogeografía, Santiago, Chile.

${ }^{4}$ Institute of Ecology and Biodiversity (IEB), Santiago, Chile

${ }^{5}$ Center for Climate and Resilience Research (CR2), Universidad de Chile, Santiago, Chile

${ }^{6}$ Department of Geography, Universidad de Chile, Santiago, Chile.

${ }^{7}$ Centre for Ecosystem Science, University of New South Wales, Sydney, New South Wales, Australia

${ }^{8}$ New South Wales Office of Environment and Heritage, Hurstville, New South Wales, Australia

${ }^{9}$ Long Term Ecological Research Network, Terrestrial Ecosystem Research Network, Australian National University, Canberra, Australian Capital Territory, Australia

${ }^{10}$ IUCN Commission on Ecosystem Management, Gland Switzerland

${ }^{10}$ IUCN Species Survival Commission, Gland, Switzerland

Keywords: Ecosystem conservation, Policy instruments, Conservation planning, Assessment criteria, land use planning, Threatened ecosystems, Prioritization.

Corresponding author: alberto.alaniz@ug.uchile.cl 


\begin{abstract}
Threats to natural ecosystems are closely linked to human development, and the lack, insufficiency or inefficiency of public policies are some of the most important drivers of negative effects on the environment. The contribution of the IUCN's Red List of Ecosystems (RLE) to conservation topics has been discussed in previous studies; however, to date its implications for conservation in public policies have not been addressed. This perspective discusses how the RLE may support the improvement and development of these policies, specifically through the implications for public policy of each of the criteria that substantiate the threat status of ecosystems. We aim to provide a plausible baseline to the operationalization of RLE in public and conservation policy, facilitating the work of governments, practitioners and decision makers. Finally, we provide recommendations and examples as to how to proceed in creating and modifying different public policy instruments, such as land-use planning, spatial zoning, tax reduction, compensation schemes, climate change adaptation plans, management of introduced species, development offsets and restoration investment. This perspective contributes to implement RLE into public policy and to improve ecosystem conservation by expanding the current scope of RLE into practical and political dimensions through plausible actions, policies and strategies.
\end{abstract}

\title{
Introduction
}

The extinction of species and the collapse of ecosystems are closely linked to human development, the intensification of production systems and the change of land use (Tilman et al. 2017). This problem has aroused interest in scientists around the world, which has led to the development of a series of planning methodologies that aim to maintain global 
biological diversity (Pimm et al. 2014; Sutherland et al. 2014; Seppelt et al. 2016; Tilman et al. 2017). To date most efforts have been at the levels of species and populations, where a great deal of progress has been made using instruments such as the red lists of threatened species and their implementation through guidelines and regulations (Pimm et al. 2014). In contrast, ecosystem-level diversity has been neglected, although the recently developed Red List of Ecosystems (RLE) offers an opportunity to accomplish internationally agreed conservation goals such as Aichi targets or sustainable development goals and to correct the conservation debt with this ecological level (Bland et al., 2016). Methodological guidelines have been developed to support applications of national and subnational RLEs (Keith et al., 2013; Rodriguez et al., 2015; Bland et al., 2016), however there is yet little guidance on how to operationalize and implement RLEs in public and conservation policy (Keith et al. 2015).

The RLE method comprises five criteria and a series of thresholds to determine an ecosystem's risk of collapse (an analogous concept to that of extinction for species): A) reduction in the distribution, B) restricted distribution, C) degradation of abiotic functional processes D) disruption of biotic functional processes, and E) quantitative analysis of the risk of collapse (Keith et al. 2013; Rodríguez et al. 2015). Having a robust methodology to classify ecosystems, recognizing their spatially explicit dimension and knowing the sources of threat promotes the application and improvement of a series of policies which could improve ecosystem-level outcomes for biodiversity conservation (Keith, 2015). Our aim is to represent a framework to governments and practitioners by suggesting ways to operationalize RLE in public policies and regulatory instruments such as land-use and 
socioeconomic planning, national and local conservation, climate change agendas and productive practices regulatory instruments, among others.

\section{Land-use planning and public policy}

A key property of ecosystems relevant to land-use planning is their explicit spatial component. Spatial information on the location of ecosystems at elevated levels of risk enables controls or restrictions on certain land uses to ensure the conservation or restoration of these remnant ecosystems. As well, the identification of threatened remnant ecosystems makes it possible to implement measures depending on their territorial context (for example, land tenure). This is important because a significant proportion of ecosystems that face high risks are those close to areas of high human activity with rapid land use changes; not necessarily those found within the protected areas (PA) (Joppa \& Pfaff 2009; Montesino Pouzols et al. 2014; Alaniz et al. 2016).

An emerging approach to land-use planning with an ecological perspective is based on the Ecosystem service (ES) concept to prioritize those ecosystems that support greater provision of services to human beings (Daily et al. 2009). While this perspective has demonstrated certain effectiveness, an exclusive focus on ecosystem services and the absence of other strategies could generate some problems. These include the fact that there are no universal assessments of ES, since a service which is beneficial for one human group might not be relevant to another, or perhaps not even for the integrity of ecosystem itself; moreover, there are biases towards ecosystems that provide a larger number/better quality of services, leaving aside those with less value from this utilitarian perspective (normally those with less biomass) (Keith et al. 2013; 2015; Deliège \& Neuteleers, 2014). The RLE should be considered complementary to the classic view of ES, allowing the development 
of universal criteria to assess risks of collapse for each ecosystem (Sutherland et al. 2014;

Keith et al. 2015). This new paradigm expands the utilitarian view of categorizing ecosystems based on anthropocentric values, normally expressed in economic terms, into an ecological view, underpinned by ecosystem functioning, which ultimately sustains services to people (Costanza et al. 2014). This approach is also systemic, because it considers changes in structural, compositional and functional characters of ecosystems, including biophysical changes as indicators of the risk of collapse (Bland et al. 2016; 2017).

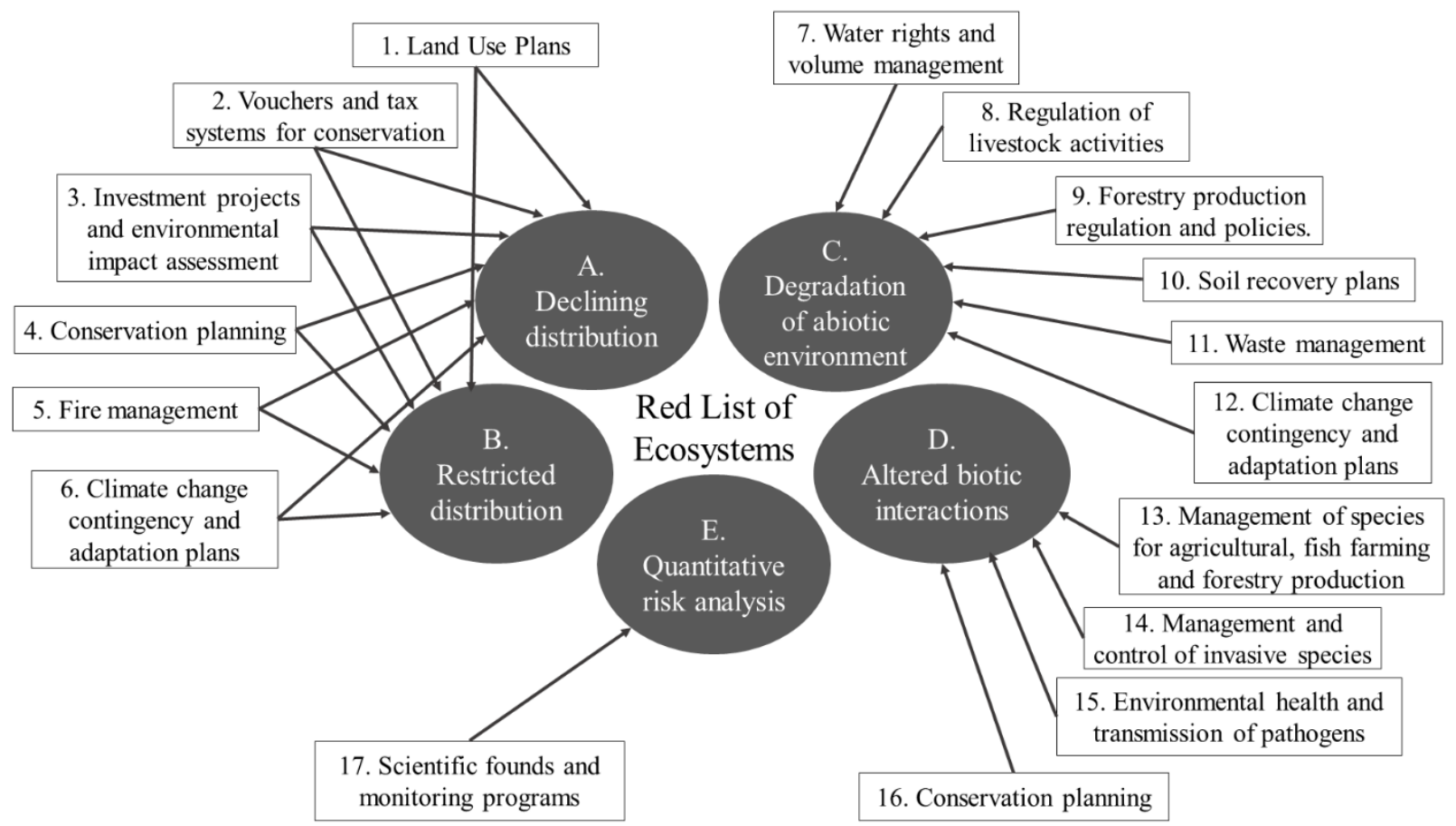

Figure 1: Relationship between Red List of Ecosystems criteria and policy instruments. Each instrument is developed in table 1 .

Each of the RLE criteria for assessing risks to ecosystems has public policy implications, since the means of abating threats ecosystems are inevitably founded in regulation, management and public policy (Busch \& Ferretti-Gallon 2017). Next, we present each of 
the RLE evaluation criteria and its implications for public policy, showing examples in different parts of the world where an ecosystem-based approach was applied (Fig. 1).

Reduction in the distribution $(A)$ : The loss and fragmentation of habitat are the main drivers of species extinction and ecosystem collapse (Pimm et al. 2014; Keith et al. 2015; Bland et al. 2017). Generally, the dynamic to reduce natural cover is associated with weak regulation of the land-use planning and development activities (Zarin et al. 2016; Busch \& Ferretti-Gallon, 2017), however some substantively regulated jurisdictions still suffer high rates of ecosystem loss (Evans 2016). Thus, threatened ecosystems identified under this criterion should be protected by: i) the development and adjustment of effective land-use regulations and plans with an ecological perspective; ii) the creation of new PA and publicprivate partnerships (private/public-private PA), to maintain and extend the spatial extent of threatened ecosystems by restricting intensive land uses in and around them (buffer zones) so as to avoid their collapse and maximize their connectivity (Table 1); iii) the effective regulation of clearing, logging and livestock grazing practices. As an example, regulation through enforcement of law to limit clearing rainforest for expansion of soy plantations in the Amazon Basin (Brazil), significantly reduced deforestation rates between 2008 to 2012 (Zarin et al. 2016; Busch \& Ferretti-Gallon, 2017).

Restricted distribution $(B)$ : Some ecosystems are intrinsically restricted, which makes them very vulnerable to anthropic and natural disturbances (Keith et al. 2013: Rodríguez et al. 2015). Therefore, ecosystems that are threatened due to their restricted distribution should be managed to avoid future impacts and maintain suitable environmental conditions at their locations (Auld and Leishman 2015). In such cases, public or private PA can be effective and efficient means of conserving these unique ecosystems, while provisions in land-use 
plans can be important complementary measures (Table 1). The fact that these ecosystems have a restricted distribution allows relatively small PAs to conserve a large portion of their distribution. In cases where processes other than land use change threaten the persistence of restricted ecosystems, the effectiveness of PA will depend on their management plans and efficacy of implementation (IUCN 2017). As an example Gnarled Mossy Cloud Forest in Lord Howe Island (Australia), have been classified as critically endangered based on their restricted distribution with continuing decline, where Australian government have leading conservation and recovery strategies focused on monitoring and detection of climate change impacts, control and eradication of rats and weeds, implementation of quarantine plan among others (Auld and Leishman 2015).

Degradation of abiotic processes $(C)$ : The causes of degradation of abiotic ecosystem components are manifold, such as excessive water extraction from rivers or groundwater, soil erosion, climate change, pollution, etc. (Keith et al. 2013). Ecosystems that have not undergone a significant reduction of their distribution could undergo far-reaching changes in some of their abiotic characteristics, which could affect their persistence (Keith et al. 2013). Actions to maintain the functional dynamics of the ecosystems listed under this criterion should include policies to reduce the intensity, frequency or spatial extent of the disturbance. One example is the creation and control of regulations to manage the volume and timing water extraction in a river basin to limit impacts on water-dependent forests or wetlands downstream (Keith 2015). On the other hand, documenting the number, identity, extent and values of ecosystems identified as threatened by climate change under criterion $\mathrm{C}$, will help to quantify public benefit in committing to strong mitigation policies, particularly through emission reductions, as well as identifying refugia for strategic 
protection into the future. In contrast, climate adaptation strategies are more spatially structured and relevant to local policy instruments at both short and long term (Pecl et al. 2017) (Table 1). For example, in Wellington (New Zealand) the climate change mitigation and adaptation strategies for coastal zones has been designed under an ecosystem based approach, integrating direct interventions through managed retreat, the construction of a seawall and raised reclamation lands (WCC, 2013) aiming to protect coastal and estuarine ecosystems. On the other hand, plans such as the Comprehensive Everglades Restoration Plan (USA) have proven to be effective for restoring soil conditions and $\mathrm{C}$ sequestration in the ecosystem (Osborne et al. 2017). A similar experience was observed in Windhoek (Namibia), where a series of restoration programs achieved return of groundwater levels in the aquifers (Sinclair et al. 2018).

Degradation of biotic interactions $(D)$ : This criterion identifies ecosystems at risk from modification of interactions among biota, such as trophic networks, declines of keystone or foundation species, functional processes (e.g carbon sequestration or nitrogen fixation), ecological interactions, changes to phenological cycles, the arrival of invasive species and pathogens, among others (Keith et al. 2013). Ecosystems assessed as threatened under this criterion should motivate government authorities to respond: i) with investment in scientific research and monitoring of biotic processes to identify the possible causes and mechanisms of degradation, ii) by developing control and eradication plans for invasive species, and by improving the regulations for the importation and quarantine of new species; and iii) by supporting initiatives for restoration in degraded ecosystems (Table 1). For example, the introduction of species for commercial purposes such as bees have altered pollination functions and the community stability, induced virulent diseases and suppressed plant 
reproduction success (worldwide) (Vanbergen et al. 2018). In USA the National Wild Pig Task Force was stablished as a part of the National Feral Swine Damage Management Program. This policy is accomplishing significant advances on control of invasive wild pigs in north American natural ecosystems (Beasley et al. 2018). Similarly, in Mercury Islands (New Zealand), the eradication of rats through control and restoration programs allowed to return nitrogen in different trophic levels (Sinclair et al. 2018). Conversely, policies to reintroduce predators have proven to reestablish the trophic webs in the Serengeti (Tanzania) (Sinclair et al. 2018).

Quantitative analysis of the risk of collapse $(E)$ : With this criterion the probability of collapse of the ecosystem can be determined on the basis of a large amount of data and predictive models (Keith et al. 2013). These models enable interactions between different threats to be examined and the merits of alterative policy and management scenarios to be explored by simulation. While data requirements may preclude the application of this criterion on a national or regional scale, the assessment and monitoring of some ecosystems of particular interest is already underway, particularly for ecosystems that support commercial fisheries (Bland et al. 2017). To do this, public programs or agreed industry plans for long-term research of these ecosystems are needed to create quality models that can anticipate changes, and demonstrate the value of research and monitoring for informing strategic ecosystem management. A study developed to monitor biological and chemical trends in temperate still waters in lakes from Australia, Canada, USA, UK, Netherland and France has shown the value of citizen science data (Thornhill et al. 2018). On the other hand, the use of Google Earth Engine platforms supported annual monitoring of USA 
rangelands from 1984 to 2017 (Jones et al. 2018). Both examples support application of criterion $\mathrm{E}$ and its role in informing strategic management decisions.

Table 1: Links between Red List criteria that support the threat level of ecosystems and public policy options for addressing respective risks.

\begin{tabular}{|c|c|c|}
\hline Criterion & $\begin{array}{l}\text { Potential threats to } \\
\text { biodiversity }\end{array}$ & $\begin{array}{l}\text { Instruments and public policies and their implications for the } \\
\text { conservation of biodiversity }\end{array}$ \\
\hline \multirow[t]{2}{*}{$\begin{array}{l}\text { A) Reduction in } \\
\text { distribution and } \\
\text { B) Restricted } \\
\text { distribution }\end{array}$} & $\begin{array}{l}\text { Change of land use and } \\
\text { cover resulting from the } \\
\text { expansion of productive } \\
\text { land uses and infrastructure } \\
\text { at the expense of natural } \\
\text { cover. }\end{array}$ & $\begin{array}{l}\text { 1.- Land-use plans: } \\
\text { - Identify threatened remnant ecosystems (vulnerable, endangered and } \\
\text { critically endangered), delimiting their specific location in the territory. } \\
\text { - Evaluate current land uses based on the threat category of the } \\
\text { ecosystems, considering the distribution of the ecosystem and } \\
\text { surrounding areas. } \\
\text { - Establish modifications to the permitted land uses and covers based on } \\
\text { the threat level. } \\
\text { From this, actions of prevention, mitigation or restoration can be } \\
\text { undertaken based on the potential impact of the land use on the } \\
\text { threatened ecosystem. } \\
\text { - Zone on the basis of the threat level, avoiding the confluence of such } \\
\text { uses as industrial, residential and/or productive with a heavy impact on } \\
\text { ecosystems with a high threat level. } \\
\text { - Constantly re-evaluate land-use plans with a view to adaptive } \\
\text { management, improving the state of the threatened ecosystems and } \\
\text { maintaining those not under threat. } \\
\text { 2.- Vouchers and tax systems for conservation } \\
\text { - Where land ownership is private, it is recommended that benefits such } \\
\text { as vouchers and reduced taxes be focused on maintaining threatened } \\
\text { remnant ecosystems on private property. } \\
\text { - If the privately owned property is apt for productive use (agricultural, } \\
\text { forestry, etc.), strategies should be developed to provide for the } \\
\text { maintenance of the area covered by the threatened remnant ecosystems. } \\
\text { On the other hand, benefits should be granted for changing to clean, } \\
\text { sustainable production, reducing the edge effect from the surrounding } \\
\text { cover. } \\
\text { - Evaluate the protected wildland systems seeking to improve the } \\
\text { representation of ecosystems with a significant reduction in their } \\
\text { distribution. } \\
\text { - Areas near threatened ecosystems should have special restrictions and } \\
\text { requirements for the development of investment projects that impact } \\
\text { their distribution. } \\
\text { 4.- Conservation planning }\end{array}$ \\
\hline & $\begin{array}{l}\text { Forest fires: the occurrence } \\
\text { of forest fires can reduce the } \\
\text { distribution of ecosystems. }\end{array}$ & $\begin{array}{l}\text { 5.- Fire management } \\
\text { - Identify and monitor in particular the occurrence of fires in threatened } \\
\text { ecosystems, identifying areas of latent risk based on the occurrence of } \\
\text { events. }\end{array}$ \\
\hline
\end{tabular}




\begin{tabular}{|c|c|c|}
\hline & & $\begin{array}{l}\text { - Reduce the occurrence of fires in threatened ecosystems by limiting } \\
\text { some human activities such as camping, agricultural burns and the use } \\
\text { of machinery. } \\
\text { - Extend firewall areas on productive lands (especially of exotic } \\
\text { plantations) around threatened ecosystems. }\end{array}$ \\
\hline & Climate change & $\begin{array}{l}\text { 6.- Climate change contingency and adaptation plans } \\
\text { - Climate change can alter the distribution of ecosystems (especially in } \\
\text { marine and freshwater ecosystems); therefore, governments should } \\
\text { anticipate potential changes in distribution, so they can react } \\
\text { opportunely by implementing territorial policies. }\end{array}$ \\
\hline \multirow[t]{4}{*}{$\begin{array}{l}\text { C) Disruption of } \\
\text { abiotic processes. }\end{array}$} & $\begin{array}{l}\text { Water reduction: poor } \\
\text { management of water } \\
\text { volumes can cause shortages } \\
\text { and modify the physical } \\
\text { processes in ecosystems }\end{array}$ & $\begin{array}{l}\text { 7.- Water rights and volume management } \\
\text { - The granting of water extraction rights and the use of water flows } \\
\text { should consider the threat level of ecosystems connected by water to } \\
\text { the extraction sources, and therefore are threatened due to the lack of } \\
\text { water. } \\
\text { - Water rights should be restricted in highly threatened ecosystems, on } \\
\text { the other hand, at sites where the impact has already occurred; owners } \\
\text { of such rights should be required to undertake mitigation and repair } \\
\text { measures to restore the characteristics of the ecosystem in question. } \\
\text { - The conservation of aquifers is necessary to support ecosystems } \\
\text { threatened by water depletion. } \\
\text { - To stablish protection zones around rivers and other water reservoirs }\end{array}$ \\
\hline & $\begin{array}{l}\text { Soil loss and erosion: poor } \\
\text { land use management, } \\
\text { associated with activities } \\
\text { like livestock farming and } \\
\text { forestry can endanger } \\
\text { ecosystems, affecting the } \\
\text { amount and quality of the } \\
\text { soil as well as plant } \\
\text { reproduction. }\end{array}$ & $\begin{array}{l}\text { 8.- Regulation of livestock activities } \\
\text { - Livestock activities in threatened remnant ecosystems must be } \\
\text { regulated to avoid and/or reduce soil erosion. } \\
\text { - Granting vouchers to owners who have heads of cattle in or near } \\
\text { threatened ecosystems should be considered to avoid the cattle } \\
\text { trampling on natural sites. } \\
\text { 9.- Forestry production regulation and policies. } \\
\text { - It is recommended that large-scale clear-cutting on forest plantations } \\
\text { be restricted in the immediate surroundings of threatened remnant } \\
\text { ecosystems, benefitting smaller-scale felling and selective cutting on } \\
\text { productive land. } \\
\text { - The extraction of firewood and litterfall from threatened ecosystems } \\
\text { must also be restricted, so the organic properties of the soil can be } \\
\text { maintained. } \\
\text { 10.- Soil recovery plans } \\
\text { - Legal instruments must be developed that promote the recovery of soils } \\
\text { in threatened ecosystems using stimulus funding to foster the recovery } \\
\text { of degraded soils and measures to rehabilitate and restore the } \\
\text { ecosystem. }\end{array}$ \\
\hline & $\begin{array}{l}\text { Pollution: waste disposal } \\
\text { can alter the quality of the } \\
\text { air, soil and water. }\end{array}$ & $\begin{array}{l}\text { 11.- Waste management } \\
\text { - Avoid the disposal of liquid or solid waste near threatened ecosystems. } \\
\text { This is meant to avoid the dispersal of polluting agents directly and } \\
\text { diffusely towards the ecosystem. }\end{array}$ \\
\hline & Climate change & $\begin{array}{l}\text { 12.- Climate change contingency and adaptation plans } \\
\text { - Climate change can bring about changes in the functions and/or abiotic } \\
\text { characteristics of an ecosystem; the generation of scenarios through } \\
\text { models that can estimate the potential impact and anticipate changes in } \\
\text { characteristics like precipitation and temperature is recommended. } \\
\text { - Then, it is necessary to design and implement plans to maintain that } \\
\text { include the threat level of the ecosystems and the causes of the threat } \\
\text { under this criterion, making it possible to make future modifications } \\
\text { imposed by climate change. }\end{array}$ \\
\hline
\end{tabular}




\begin{tabular}{|c|c|c|}
\hline \multirow[t]{2}{*}{$\begin{array}{l}\text { D) Disruption of } \\
\text { biotic processes } \\
\text { and functions }\end{array}$} & $\begin{array}{l}\text { Biological invasions: the } \\
\text { introduction of species } \\
\text { incidentally or accidentally } \\
\text { can have significant effects } \\
\text { on the biotic interactions of } \\
\text { the ecosystem. }\end{array}$ & $\begin{array}{l}\text { 13.- Management of species for agricultural, fish farming and forestry } \\
\text { production } \\
\text { - The introduction of species for productive purposes should consider } \\
\text { the threat level of ecosystems in a radius of influence from the target } \\
\text { site, considering such characteristics as the dispersion range of the } \\
\text { species to be introduced. } \\
\text { - The arrival of new invasive individuals such as insects for pollination } \\
\text { and biological control could significantly affect the networks of } \\
\text { interaction in ecosystems that are threatened. } \\
\text { - The accidental dispersion of propagules must be included in production } \\
\text { management, thus making the companies that introduce the species } \\
\text { accountable for controlling the undesired dispersion of individuals. } \\
\text { 14.- Management and control of invasive species } \\
\text { - Invasive species already present are considered a problem in threatened } \\
\text { ecosystems; therefore, these should be controlled by facilitating access } \\
\text { to resources focused on control, as well as measures for population } \\
\text { reduction of invasive species in threatened ecosystems. } \\
\text { - It is recommended that domestic species be controlled through } \\
\text { measures like sterilization to avoid the depredation of wild fauna in the } \\
\text { ecosystem. } \\
\text { 15.- Environmental health and transmission of pathogens } \\
\text { - The presence of non-native wild or domestic species can pose serious } \\
\text { risks of the transmission of pathogens to the native fauna and flora. } \\
\text { Ecosystems threatened by disruption of their biotic interactions can be } \\
\text { vulnerable to the increased transmission of pathogens. Thus } \\
\text { management focused on reducing the potential transmission through } \\
\text { strategies like the sterilization and vaccination of domestic species like } \\
\text { felines and canines is needed. }\end{array}$ \\
\hline & $\begin{array}{l}\text { Extinction of key species } \\
\text { (ecosystem engineers, } \\
\text { trophic or structural } \\
\text { dominants, keystone or } \\
\text { foundation species, etc): } \\
\text { The reduction of the } \\
\text { populations of key species } \\
\text { can significantly affect the } \\
\text { operation of the ecosystem. }\end{array}$ & $\begin{array}{l}\text { 16.- Conservation planning } \\
\text { - Studies must be conducted that seek to explain the structures of the } \\
\text { interaction networks in ecosystems threatened by the biotic disruption } \\
\text { of processes and interactions. } \\
\text { - Then, measures should be implemented to improve and increase the } \\
\text { populations of key species that are experiencing a significant reduction. } \\
\text { - Measures such as the declaration of a threat category for these species } \\
\text { must be considered, using for example the red list of species. } \\
\text { - Design and maintenance of biological corridors in fragmented } \\
\text { landscapes with presence of endangered ecosystems. }\end{array}$ \\
\hline $\begin{array}{l}\text { E) Quantitative } \\
\text { analysis of the } \\
\text { risk of collapse: }\end{array}$ & $\begin{array}{l}\text { Sum of threatening } \\
\text { processes associated with } \\
\text { some of the causes } \\
\text { previously set out or with a } \\
\text { combination of these. }\end{array}$ & $\begin{array}{l}\text { 17.- Scientific founds and monitoring programs } \\
\text { In this case, scientific research and monitoring programs are recommended } \\
\text { for the case of ecosystems with high threat levels in order to generate } \\
\text { models that can predict the collapse. } \\
\text { Models should be used to explore and compare the outcomes of alterative } \\
\text { ecosystem management strategies. }\end{array}$ \\
\hline
\end{tabular}

\section{Action strategies and monitoring of ecosystems}

It is important to emphasize that often the same ecosystem can be threatened by multiple factors (reduction of the distribution, alteration of processes, etc.); therefore, the response cannot be only one action, but must be strategic and systemic, where a variety of public 
policy instruments are implemented on different spatiotemporal scales to ensure ecosystem conservation. Not all the criteria necessarily classify the same ecosystem in the same category of risk, which makes it possible to prioritize the actions aimed at tackling the causes responsible for the highest risks, as identified by the criterion returning the highest category. The RLE-based classification method therefore supports land-use planning decisions by highlighting where in the landscape application of spatially explicit conservation policies, targets, strategies and actions (corrective or preventive) would most benefit the reduction of risks (Keith, 2015). The goals should be oriented towards abating the threats to ecosystems to reduce their category of risk. Proactively, for ecosystems currently at low levels of risk, the aim would be to maintain that status. Yet conservation action is often delayed until ecosystems become threatened, limiting the options for effective action and often increasing the costs.

Another important benefit of using RLE in land-use planning is that it facilitates informing and educating a wide and varied public about the need to protect a given ecosystem. Red lists of species (terms, foundations, etc.) are well known as conservation instruments, which facilitates the integration of the RLE in public policies and the engagement on different actors (Keith et al., 2015; Bland et al., 2017). In the same vein, countries such as Vietnam and Japan have operationalized red lists in institutional and normative terms, by enacting a series of laws and decrees about red list of species (Do et al. 2018) and establishing governance networks with stakeholders for endangered species conservation (Yamaki 2015). These precedents can facilitate the installation and operation of the RLE at national and supranational levels. 
The RLE can help to formulate management regimes for PAs. For example, PAs containing ecosystems with the highest levels of risk should have strict biodiversity objectives (IUCN categories I and II). Therefore, in these cases normative planning instruments should be used, while trying to avoid flexible indicative instruments that permit human activities. This requires the development of institutional and regulatory capacities for the operationalization of the RLE, as well as good ecosystem monitoring indicators and the broadening and optimization of data collection (Bland et al. 2016; Rowland et al. 2018). There are currently many usable methodologies to monitor ecosystems, which include A) remote sensing, which through the use of satellite information makes it possible to monitor structural and functional variables in the ecosystem (Pettorelli et al. 2017; Murray et al. 2018; Jones et al. 2018), B) In situ monitoring of community variables like the estimation of species composition, diversity, functional groups and trophic functions, C) In situ monitoring of ecosystem functioning through micro-meteorological instruments that can obtain energy flows and gas exchange between the ecosystem and the atmosphere.

\section{Conservation and prioritization of ecosystems}

The strategies to implement conservation efficiently often combine public-private scenarios across PAs in natural areas and planning and management strategies in agricultural, forestry, fisheries and livestock environments. The RLE can support public policy for conservation in both environments.

Conservation in production systems: A significant proportion of the ecosystems that are threatened are close to areas of high human influence (Crespin \& Simonetti, 2015; Alaniz et al. 2016), and are generally outside PAs. Land ownership and value poses significant barriers to creating PAs on productive lands; thus, strategies to reconcile conservation of 
biodiversity with production environments are among the most important challenges of the 21st century (Seppelt et al. 2016; Montesino Pouzols et al. 2014). To address this challenge, public investments through mechanisms such as tax exemptions, green bonds, ecological product certifications, subsidies and stewardship payments could be targeted to support land owners to maintain and conserve endangered ecosystems identified by RLE assessments as is done to maintain endangered species (Table 1). In Canada tax shifting to land-owners on coastal Douglas fir ecosystems increased the area under protection from $9 \%$ to $17 \%$, reaching the Convention on Biological Diversity target (Schuster et al. 2017). In Indonesia the oil palm Roundtable Sustainable Certification lowered deforestation rates of rainforest by $33 \%$ between 2001 to 2015 (Carlson et al. 2018). These examples highlight the ability of these mechanisms, to achieve conservation goals.

Conservation planning: The RLE has potential to weigh the threat level of ecosystems in systematic conservation planning (Keith, 2015). This could significantly improve the design of new PAs and performance evaluation of those already existing. RLE could allow to define the management category of a new protected area according to IUCN (I, II, III, IV, $\mathrm{V}$ or VI), taking the threat status or category of the ecosystem to be conserved as a reference. In addition, the zoning of PAs already created could be redefined and reconstructed, defining the creation of primitive and multiple use zones on the basis of the category of the ecosystems represented in the area. As example, it has been proposed that expand marine PAs to include degraded coral reefs in order to improve the conservation of these types of ecosystems (Abelson et al. 2016), in this case an RLE approach will be useful on prioritizing ecosystems for protected area design and restoration. 
Ecosystems may be prioritized by considering their importance for supply of ES, however, the RLE could strengthen prioritization for conservation targets by assigning weights to ecosystems according to threat status. This way, it could be ensured that a new PAs are designed to protect examples of the most threatened ecosystems. It is worth emphasizing the complementarity of RLE and ES approaches for achieving multiple conservation goals motivated by both intrinsic and utilitarian values, recognizing that progress on each can contribute $t$ achieving the other.

\section{Conclusions}

It is recommended that governments, non-government organizations, industries, practitioners and research entities stimulate the development of national and local RLEs, as well as their application to resource use and development decisions through conservationfocused public policies and industry development policies. The RLE is not limited only to traditional conservation topics, such as the design and evaluation of PAs, prioritization of conservation sites and ecological restoration, among others, but also has great potential as a fundamental component in the design of integral land-use and zoning plans, as well as macro-economic policy (e.g. through investment and taxation strategies). We hope that this article opens discussion for new guidelines for the application of RLEs in public policy. Nevertheless, many of the initiatives described here are ultimately influenced by the local contexts of each territory. The ideas and examples detailed here may be adapted to the sociocultural, economic, politico-institutional contexts of each country, thereby promoting the effectiveness of public policies for the conservation of biodiversity. 


\section{References}

Abelson, A., Nelson, P.A., Edgar, G.J., Shashar, N., Reed, D.C., Belmaker, J., Krause, G., Beck, M.W., Brokovich, E., France, R. \& Gaines, S.D. (2016). Expanding marine protected areas to include degraded coral reefs. Conserv. Biol., 30, 1182-1191.

Alaniz, A.J., Galleguillos, M. \& Perez-Quezada, J.F. (2016). Assessment of quality of input data used to classify ecosystems according to the IUCN Red List methodology: The case of the central Chile hotspot. Biol. Conserv., 204, 378-385.

Auld, T.D. \& Leishman, M.R. (2015). Ecosystem risk assessment for Gnarled Mossy Cloud Forest, Lord Howe Island, Australia. Austral Ecol., 40, 364-372.

Beasley, J.C., Ditchkoff, S.S., Mayer, J.J., Smith, M.D. \& Vercauteren, K.C. (2018).

Research priorities for managing invasive wild pigs in North America. J. Wildl. Manage., $82,674-681$.

Bland, L.M., Keith, D.A., Miller, R.M., Murray, N.J. and Rodríguez, J.P. (eds.) (2016). Guidelines for the application of IUCN Red List of Ecosystems Categories and Criteria, Version 1.0. Gland, Switzerland: IUCN. ix + 94pp.

Bland, L.M., Rowland, J.A., Regan, T.J., Keith, D.A., Murray, N.J., Lester, R.E., Linn, M., Rodríguez, J.P. \& Nicholson, E. (2017). Developing a standardized definition of ecosystem collapse for risk assessment. Front. Ecol. Environ. 16(1):29-36.

Busch, J. \& Ferretti-Gallon, K. (2017). What drives deforestation and what stops it? A meta-analysis. Rev. Environ. Econ. Policy, 11, 3-23. 
Carlson, K.M., Heilmayr, R., Gibbs, H.K., Noojipady, P., Burns, D.N., Morton, D.C., Walker, N.F., Paoli, G.D. \& Kremen, C. (2017). Effect of oil palm sustainability certification on deforestation and fire in Indonesia. Proc. Natl. Acad. Sci., 115, 201704728.

Crespin, S.J. \& Simonetti, J.A. (2015). Predicting ecosystem collapse: Spatial factors that influence risks to tropical ecosystems. Austral Ecol., 40, 492-501.

Costanza, R., de Groot, R., Sutton, P., van der Ploeg, S., Anderson, S.J., Kubiszewski, I., Farber, S. \& Turner, R.K. (2014). Changes in the global value of ecosystem services. Glob. Environ. Chang., 26, 152-158.

Daily, G.C., Polasky, S., Goldstein, J., Kareiva, P.M., Mooney, H.A., Pejchar, L., Ricketts, T.H., Salzman, J. \& Shallenberger, R. (2009). Ecosystem services in decision making: Time to deliver. Front. Ecol. Environ., 7, 21-28.

Deliège, G. \& Neuteleers, S. (2014). Ecosystem services as an argument for biodiversity preservation: Why its strength is its Problem - Reply to Cimon-Morin et al. Biol. Conserv., $172,218$.

Do, T.H., Krott, M., Juerges, N. \& Böcher, M. (2018). Red lists in conservation sciencepolicy interfaces: A case study from Vietnam. Biol. Conserv., 226, 101-110.

Evans, M. C. (2016). Deforestation in Australia: drivers, trends and policy responses. Pac. Conserv. Biol. 22, 130-150.

Jones, M.O., Allred, B.W., Naugle, D.E., Maestas, J.D., Donnelly, P., Metz, L.J., Karl, J., Smith, R., Bestelmeyer, B., Boyd, C., Kerby, J.D. \& McIver, J.D. (2018). Innovation in rangeland monitoring: annual, $30 \mathrm{~m}$, plant functional type percent cover maps for U.S. rangelands, 1984-2017. Ecosphere, 9, e02430. 
Joppa, L.N. \& Pfaff, A. (2009). High and far: Biases in the location of protected areas. PLoS One, 4, 1-6.

IUCN and World Commission on Protected Areas (WCPA) (2017). IUCN Green List of Protected and Conserved Areas: Standard, Version 1.1. Gland, Switzerland: IUCN. https://iucn.my.salesforce.com/sfc/p/\#24000000e5iR/a/1o0000005CYr/tm09GdOqZJyZyf. PA2BWk3msdbep3O9Xomyt5wNVGuw

Keith, D.A., Rodríguez, J.P., Brooks, T.M., Burgman, M.A., Barrow, E.G., Bland, L., Comer, P.J., Franklin, J., Link, J., Mccarthy, M.A., Miller, R.M., Murray, N.J., Nel, J., Nicholson, E., Oliveira-Miranda, M.A., Regan, T.J., Rodríguez-Clark, K.M., Rouget, M. \& Spalding, M.D. (2015). The IUCN red list of ecosystems: Motivations, challenges, and applications. Conserv. Lett., 8, 214-226.

Keith, D.A., Rodríguez, J.P., Rodríguez-Clark, K.M., Nicholson, E., Aapala, K., Alonso, A., Asmussen, M., Bachman, S., Basset, A., Barrow, E.G., Benson, J.S., Bishop, M.J., Bonifacio, R., Brooks, T.M., Burgman, M.A., Comer, P., Comín, F.A., Essl, F., FaberLangendoen, D., Fairweather, P.G., Holdaway, R.J., Jennings, M., Kingsford, R.T., Lester, R.E., Nally, R. Mac, McCarthy, M.A., Moat, J., Oliveira-Miranda, M.A., Pisanu, P., Poulin, B., Regan, T.J., Riecken, U., Spalding, M.D. \& Zambrano-Martínez, S. (2013). Scientific Foundations for an IUCN Red List of Ecosystems. PLoS One, 8, e62111.

Montesino Pouzols, F., Toivonen, T., Di Minin, E., Kukkala, A.S., Kullberg, P., Kuusterä, J., Lehtomäki, J., Tenkanen, H., Verburg, P.H. \& Moilanen, A. (2014). Global protected area expansion is compromised by projected land-use and parochialism. Nature, 516, 383. 
Murray, N.J., Keith, D.A., Bland, L.M., Ferrari, R., Lyons, M.B., Lucas, R., Pettorelli, N. \& Nicholson, E. (2018). The role of satellite remote sensing in structured ecosystem risk assessments. Sci. Total Environ., 619-620, 249-257.

Osborne, T.Z., Fitz, H.C. \& Davis, S.E. (2017). Restoring the foundation of the Everglades ecosystem: assessment of edaphic responses to hydrologic restoration scenarios. Restor. Ecol., 25, S59-S70.

Pecl, G.T., Araújo, M.B., Bell, J.D., Blanchard, J., Bonebrake, T.C., Chen, I.-C., Clark, T.D., Colwell, R.K., Danielsen, F., Eveng\r ard, B., Falconi, L., Ferrier, S., Frusher, S., Garcia, R.A., Griffis, R.B., Hobday, A.J., Janion-Scheepers, C., Jarzyna, M.A., Jennings, S., Lenoir, J., Linnetved, H.I., Martin, V.Y., McCormack, P.C., McDonald, J., Mitchell, N.J., Mustonen, T., Pandolfi, J.M., Pettorelli, N., Popova, E., Robinson, S.A., Scheffers, B.R., Shaw, J.D., Sorte, C.J.B., Strugnell, J.M., Sunday, J.M., Tuanmu, M.-N., Vergés, A., Villanueva, C., Wernberg, T., Wapstra, E. \& Williams, S.E. (2017). Biodiversity redistribution under climate change: Impacts on ecosystems and human well-being. Science (80) 355.

Pettorelli, N., Schulte to Bühne, H., Tulloch, A., Dubois, G., Macinnis-Ng, C., Queirós, A.M., Keith, D.A., Wegmann, M., Schrodt, F., Stellmes, M., Sonnenschein, R., Geller, G.N., Roy, S., Somers, B., Murray, N., Bland, L., Geijzendorffer, I., Kerr, J.T., Broszeit, S., Leitão, P.J., Duncan, C., El Serafy, G., He, K.S., Blanchard, J.L., Lucas, R., Mairota, P., Webb, T.J. \& Nicholson, E. (2017). Satellite remote sensing of ecosystem functions: opportunities, challenges and way forward. Remote Sens. Ecol. Conserv., 71-93. 
Pimm, S.L., Jenkins, C.N., Abell, R., Brooks, T.M., Gittleman, J.L., Joppa, L.N., Raven, P.H., Roberts, C.M. \& Sexton, J.O. (2014). The biodiversity of species and their rates of extinction, distribution, and protection. Science (80), 344.

Rodriguez, J.P., Keith, D.A., Rodriguez-Clark, K.M., Murray, N.J., Nicholson, E., Regan, T.J., Miller, R.M., Barrow, E.G., Bland, L.M., Boe, K., Brooks, T.M., Oliveira-Miranda, M.A., Spalding, M. \& Wit, P. (2015). A practical guide to the application of the IUCN Red List of Ecosystems criteria. Philos. Trans. R. Soc. B Biol. Sci., 370, 20140003-20140003.

Rowland, J.A., Nicholson, E., Murray, N.J., Keith, D.A., Lester, R.E. \& Bland, L.M. (2018). Selecting and applying indicators of ecosystem collapse for risk assessments. Conserv. Biol., 32, 1233-1245.

Schuster, R., Law, E.A., Rodewald, A.D., Martin, T.G., Wilson, K.A., Watts, M., Possingham, H.P. \& Arcese, P. (2017). Tax Shifting and Incentives for Biodiversity Conservation on Private Lands. Conserv. Lett., 11, e12377.

Seppelt, R., Beckmann, M., Ceauşu, S., Cord, A.F., Gerstner, K., Gurevitch, J., Kambach, S., Klotz, S., Mendenhall, C., Phillips, H.R.P., Powell, K., Verburg, P.H., Verhagen, W., Winter, M. \& Newbold, T. (2016). Harmonizing biodiversity conservation and productivity in the context of increasing demands on landscapes. Bioscience, 66, 890-896.

Sinclair, A.R.E., Pech, R.P., Fryxell, J.M., McCann, K., Byrom, A.E., Savory, C.J., Brashares, J., Arthur, A.D., Catling, P.C., Triska, M.D., Craig, M.D., Sinclair, T.J.E., McLaren, J.R., Turkington, R., Beyers, R.L. \& Harrower, W.L. (2018). Predicting and Assessing Progress in the Restoration of Ecosystems. Conserv. Lett., 11, 1-10. 
Sutherland, W.J., Aveling, R., Brooks, T.M., Clout, M., Dicks, L. V, Fellman, L.,

Fleishman, E., Gibbons, D.W., Keim, B., Lickorish, F., Monk, K.A., Mortimer, D., Peck, L.S., Pretty, J., Rockström, J., Rodríguez, J.P., Smith, R.K., Spalding, M.D., Tonneijck, F.H. \& Watkinson, A.R. (2014). A horizon scan of global conservation issues for 2014. Trends Ecol. Evol., 29, 15-22.

Thornhill, I., Chautard, A. \& Loiselle, S. (2018). Monitoring biological and chemical trends in temperate stillwaters using citizen science. Water 10.

Tilman, D., Clark, M., Williams, D.R., Kimmel, K., Polasky, S. \& Packer, C. (2017).

Future threats to biodiversity and pathways to their prevention. Nature, 546, 73.

Vanbergen, A.J., Espíndola, A. \& Aizen, M.A. (2018). Risks to pollinators and pollination from invasive alien species. Nat. Ecol. Evol., 2, 16-25.

WCC e Wellington City Council, 2013. Sea Level Rise Options Analysis. Tonkin \& Taylor Ltd, Wellington.

Yamaki, K. (2015). Network governance of endangered species conservation: A case study of Rebun Lady’s-Slipper. J. Nat. Conserv., 24, 83-92. 